\title{
Paradise of territoriality lost: rethinking extraterritoriality in administrative law
}

\author{
Full professor Jakub HANDRLICA ${ }^{1}$
}

\begin{abstract}
Traditionally, the scholarship of administrative law has paid only very limited attention to the phaenomenon of extraterritoriality. Hereby, the scholarship has reflected the theoretical considerations concerning the sovereignty of the State, which have implied that administrative authorities execute their functions exclusively in the territory of the State. At the same time, the scholarship of international public law has traditionally acknowledged that - as based on a corresponding international agreement - a State may allow the administrative authorities of a foreign State to execute certain functions in its own territory. This article aims to reconcile these two approaches, demonstrating that the phaenomenon of extraterritoriality has emerged to represent an integral part of the system of administrative law in various jurisdictions. This article also argues that this perception of administrative law actually fails to represent any new feature, but is based on traditional concepts existing in the public law of Europe. Thus, extraterritoriality must be considered as a part of the ius publicum europaeum commune.
\end{abstract}

Keywords: extraterritoriality; territorial paradigm; international administrative law; ius publicum europaeum commune, administrative law beyond the state; comparative public law.

JEL Classification: K23, K32

DOI: $10.24818 / \mathrm{TBJ} / 2021 / 11 / 3.06$

\section{Introduction ${ }^{2}$}

An uninformed walker might be easily surprised when strolling through the National Gardens in the very centre of Athens, originally designed by Queen Amalia $^{3}$ as the royal gardens. However, it is a well a well-known secret among Athenians that the 15-hectare wooded park in the midst of the Greek capital is home

\footnotetext{
${ }^{1}$ Jakub Handrlica - full professor of Administrative Law, Faculty of Law, Charles University, Prague, Czech Republic \& Visiting Fellow, European Law and Governance School, Athens, Hellenic Republic, https://orcid.org/0000-0003-2274-0221, jakub.handrlica@prf.cuni.cz.

2 This research was funded by Czech Science Agency through its project 20-01320S "International Administrative Law: Legal Discipline Rediscovered".

${ }^{3}$ Amalia of Oldenburg (1818-1875) was Queen of Greece from 1836 to 1862 as the spouse of King Otto (1815-1867). She acted as Regent of Greece in 1850-1851, when Otto was in Germany, and a second time when he visited Bavaria in 1861-1862. Amalia commissioned the establishment of the Royal Gardens (now National Gardens) in 1838. The project was designed by German agronomist Friedrich Schmidt, who imported over 500 species of plants and a variety of animals, including peacocks, ducks and turtles. The fact is, however, that for many species the dry Mediterranean climate proved to be too harsh and they failed to survive. The project was finished in 1840.
} 
to a sizeable colony of wild parrots, as well as a fluctuating number of parakeets and the odd cockatoo. ${ }^{4}$ Ornithologists believe these colonies were formed by caged parrots that escaped or, in some cases, were released by owners once their pet's novelty wore off. This theory is supported by the existence of one or two smaller colonies in small, suburban wooded parks, but the one in the National Gardens is the largest. ${ }^{5}$ Though tropical, the parrots seem to have adapted to the cold winter temperatures and a rather different diet - although their tastes seem to draw them to the leaves and berries of plants endemic to their original habitat. ${ }^{6}$

There is a clear parallel between these colonies of parrots and the subject of this article, which aims to address the issue of administrative authorities beyond the borders of the State. Very similar to a parrot in Mediterranean garden, neither is a foreign administrative authority a regular feature in domestic relations of administrative law. Also they appear to represent an alien feature, which is - in principle - not fitting into the traditional schemes of administrative law. ${ }^{7}$ However, in similar fashion as the parrots in the National Gardens of Athens, foreign administrative authorities also seem to "have adapted" to these extraordinary circumstances. ${ }^{8}$ Nowadays, various schemes of extraterritorial competences became more regular, in particular in the field of police cooperation, regulation of financial markets, competition law and the banking industry. These facts are being discussed under the umbrella of the research endeavour, which has been labelled as "administrative law beyond the territory of the State". 9

However, this article aims to argue that in strict contrast to the colony of parrots, which an astonished walker may discover in the trees of the National Gardens, the feature of extraterritorial competences in administrative law is neither

${ }^{4}$ See Alexia Amvrazi, Diana Farr Louis, Diane Shugart, 111 Places in Athens That You Shouldn't Miss (Leck: Emons Verlag GmbH, 2018): 162.

5 ibid.

${ }^{6}$ ibid.

${ }^{7}$ See Giovanni Biaggini, "Die Entwicklung eines internationalen Verwaltungsrechts als Aufgabe der Rechtswischenschaft" in Die Leistungsfähigkeit der Wissenschaft des Öffentlichen Rechts, ed. George Nolte, Ralph Poscher, Christian Hillgruber, Uwe Volkmann (Berlin: De Gruyter Recht, 2008): 413-440.

${ }^{8}$ See Ezgi Yldiz, "Extraterritoriality Reconsidered" in The Extraterritoriality of Law. History, Theory, Politics, ed. Daniel S. Margolies, Umut Özsu, Maïa Pal and Ntina Tsouvala, (Abingdon: Routledge, 2019): 215-227.

${ }^{9}$ See Anna-Sara Lind, Jane Reichel (eds), Administrative Law Beyond the State, Nordic Perspectives (Amsterdam: Brill Nijhoff, 2015), Giacinto Della Cananea, "Beyond the State: the Europeisation and globalisation of procedural administrative law", European Public Law 9, issue 4 (December 2004): 563-578, Sabino Cassese, Giulio Napolitano, Lorenzo Casini, “Towards multipolar administrative law: a theoretical perspective", International Journal of Constitutional Law 12, issue 2 (April 2014): 354-356, Joanna Mendes, "Administrative Law Beyond the State”, in Global Administrative Law and European Administrative Law. Relationship, Legal Issues and Comparison, ed. Edoardo Chiti, Bernardo G. Mattarella (Berlin: Springer Verlag, 2011): 111-132, Giulio Napolitano, "Administration Beyond the State", in Comparative Administrative Law, ed. Susan Rose-Ackermann, Peter L. Lindseth (London: Edward Elgar, 2010): 320-322, Giacinto Della Cananea, "Administrative Law Beyond the State" in The Oxford Handbook of Comparative Administrative Law, ed. Peter Cane, Herwig C. H. Hofmann, Eric C. Ip, Peter L. Lindseth (Oxford: Oxford University Press, 2020): 675-686 etc. 
purely a feature, nor a product of the latest developments. This article argues that this feature has been part of international public law for a long time. It has been the strict territorial perception of administrative law in various European jurisdiction, which hindered any detailed research of this phaenomenon.

In this respect, this article aims to argue that extraterritoriality has for decades represented an integral part of administrative law and has been part of the ius publicum europaeum commune. ${ }^{10}$ This article also aims to represent a contribution to the scholarship of international administrative law, which intends to study foreign elements in the relations of administrative law. ${ }^{11}$

\section{The two faces of extraterritoriality in administrative law}

Traditionally, the scholarship of administrative law has paid only very limited attention to the phaenomenon of extraterritoriality. ${ }^{12}$ This disinterest on the part of the classical scholarship in extraterritoriality clearly reflects a very traditional approach to the feature of sovereignty of a State. Pursuant to this traditional approach, a State executes exclusive jurisdiction over its own territory. Such jurisdiction appears in two different layers. On one hand, there is jurisdiction to prescribe rules, which means a sovereign State has the power to design rules of public law in its own territory. On the other hand, the jurisdiction to enforce represented another part of the State's sovereignty over a territory, implying that only the authorities of the State are competent to enforce the rules of public law. ${ }^{13}$

Thus, under this traditional approach, there was no need in principle to address the phaenomenon of extraterritoriality in administrative law, so consequently the problems theoretically arising were left to the scholarship of international public law. ${ }^{14}$ When reading the handbooks on administrative law in major continental jurisdictions, an impression imminently appears that this

\footnotetext{
${ }^{10}$ See Eberhard Schmidt-Assmann, "Administrative Law in Europe: Between Common Principles and National Traditions", in Administrative Law in Europe: Between Common Principles and National Traditions, ed. Matthias Ruffert (Groningen: Europa Law Publishing, 2015): 3-6. See also article by Matthias Ruffert, "Common Principles and National Traditions: Which Perspective for European Administrative Legal Scholarship" in the same volume, at 215-220; Cătălin-Silviu Săraru, European Administrative Space - recent challenges and evolution prospects, ADJURIS - International Academic Publisher, Bucharest, 2017, p. 15-47.

${ }^{11}$ See Jakub Handrlica, "Revisiting International Administratve Law as a Legal Discipline", Zbornik Pravnog Fakulteta Sveučilišta u Rijeci 39, issue 3 (December 2018): 1237-1258.

${ }^{12}$ See Jorge Abudo Gonzalez, "The overcoming of territorial paradigm and its effects in administrative law", Revista de derecho politico 103 (December 2018): 157-190. Also see Ming-Sung Kuo, "From administrative law to administrative legitimation: Transnational administrative law and the process of European integration", International \& Comparative Law Quarterly 61, issue 4 (October 2012): 855-879.

${ }^{13}$ See Hermann Heller, Sovereignty. A Contribution to the Theory of Public and International Law, ed. David Dyzenhaus (Oxford: Oxford University Press, 2019): 50-55.

${ }^{14}$ See John D. Haskell, "Ways of doing extraterritoriality in scholarship" in The Extraterritoriality of Law. History, Theory, Politics, ed. Daniel S. Margolies, Umut Özsu, Maïa Pal and Ntina Tsouvala (Abingdon: Routledge, 2019): 20-25.
} 
traditional approach is also being accepted today in the scholarship of administrative law in various administrative traditions of Europe. ${ }^{15}$

The fact is, however, that the scholarship of administrative law has never espoused the scope of the jurisdiction to prescribe exclusively to the territory of the State. The consequence of this perception has been twofold:

Firstly, the norms of administrative law have traditionally recognised the fact that certain persons are to be exempted from certain imposed obligations. Thus, the norms of administrative law exempt diplomatic staff from liability for certain administrative offences, obligations arising from tax, or social security legislation of the host State. ${ }^{16}$

Secondly, the norms of administrative law have also regularly considered certain facts or situations that occurred outside the territory of the State. Consequently, the norms of tax law provide for rules on income, occurring abroad, the norms of social security law reflect social security payments made in other States, the norms of competition law regulate cases of anti-competitive behaviour occurring abroad etc. In this respect, the term "extraterritoriality" or "extraterritorial" application of administrative law is being used. ${ }^{17}$ When understanding "extraterritoriality" in this way, one may indeed find a comprehensive scholarship on this phaenomenon, dealing in particular with various special fields of administrative law and with the "extraterritorial" scope of their norms. ${ }^{18}$ This is one "face" of extraterritoriality in administrative law.

In all the above-mentioned cases, the extraterritorial features arise in the proceedings before the administrative authorities, acting in "inland". However, a real undermining of the traditional link between territoriality and administrative law appears in situations when administrative authorities of one State act in the territory of another sovereign State. In such situations, the concept of territorial competence to enforce rules, traditionally reduced to the territory of a State, is blurred. Also here, we can refer to "extraterritoriality" and the term will be used in this sense in this article. This is a second "face" of extraterritoriality in administrative law.

Despite an ostentatious disinterest of the mainstream scholarship of administrative law, the phaenomenon of extraterritoriality in the above explained

${ }^{15}$ See Rocco Galli, Nuovo corso di diritto amministrativo (7. ed., Milano: CEDAM, 2019), Hartmut Maurer and Christian Waldhoff, Allgemeines Verwaltungsrecht (20. ed., Munich: C. H. Beck, 2020), Jean Sirinelli, Martine Lombard, Gilles Dumont, Droit administratif (13. ed., Paris: Dalloz, 2019, Bernard Raschauer, Allegemeines Verwaltungsrecht (5. ed., Vienna: Verlag Österreich, 2016) etc.

${ }^{16}$ See Vienna Convention on Diplomatic Relations, art. 33, 34, 35 and 36.

${ }^{17}$ See Stefano Battini, "Globalisation and Extraterritorial Regulation: An Unexceptional Exception" in Values in Global Administrative Law, ed. Gordon Anthony, Jean-Bernard Auby, John Morison and Tom Zwart (London: Hart Publishing, 2011): 65-80.

${ }^{18}$ See eg. Samuel J. Hickey, "Extraterritoriality and international bribery", Modern Law Review 83, issue 5 (September 2020): 1116-1120, Carmela D'Avigno, "Extraterritoriality of swaps regulation and regulatory arbitrage", Journal of Regulatory Economics 56, issue 2-3 (December 2019): 167187, Pierre-Hugues Verdier, "New Financial Extraterritriality", George Washington Law Review 87, issue 2 (March 2019): 239-314, Matthias Lehman, "Legal Fragmentation, Extraterritoriality and Uncertainty in Global Financial Regulation", Oxford Journal of Legal Studies 37, issue 2 (2017): 406-437 etc. 
meaning has already triggered certain attention. The fact is, however, that the authors have so far aimed to analyse appearances of extraterritoriality in selected fields of administrative law. ${ }^{19}$ In this respect, this article aims to demonstrate that the phaenomenon of extraterritoriality has emerged to represent an integral part of the system of administrative law in various jurisdictions. This article argues that this perception of administrative law does not represent a new feature, but is based on traditional concepts, existing in the public law of Europe.

\section{Arguments against extraterritoriality in administrative law}

The fact is that the scholarship of administrative law has expressed several major arguments against execution of competencies of administrative authorities beyond the borders of the State..$^{20}$ These arguments can be summarised as explained in the paragraphs bellow:

Ad 1). Every State may exercise sovereign acts in all territories where no other nation has previously established exclusive jurisdiction or where no other prohibition is valid. ${ }^{21}$ In contrast, however, every nation has a right to expect that its territorial sovereignty will be respected by other nations. In Europe, governments strived to eliminate the pre-existing territorial patchwork of Europe to achieve territorially unified, self-contained and integral nation-States. This development was finally completed in the $19^{\text {th }}$ century. The prohibition against the undertaking of sovereign acts on foreign territory follows naturally, not only from the basic principle of territorial sovereignty, but also from the principle that all States are independent. ${ }^{22}$

Consequently, the very traditional disinterest of the scholarship of administrative law in extraterritoriality has clearly reflected the above outlined general principles of international public law.

The fact is, however, that the scholarship of international public law has been aware of several exceptions to this general rule. In the case of a terra nullius, or a

19 See Manfred Baldus, Transnationales Polizeirecht (Baden Baden: NomosVerlag, 2001), Antje David, Inspektionen im Europäischen Verwaltungsrecht (Berlin: Duncker \& Humblot, 2003), Martin Kment, Grenzüberschreitendes Verwaltungshandeln. Transnationale Elemente deutscher Verwaltungsrecht (Tübingen: Mohr Siebeck, 2010), Gerrit Tönningsen, Grenzüberschreitender Bankenaufsicht in der Europäischen Union (Tübingen: Mohr Siebeck, 2018) etc. For a more comprehensive approach to this topic, see Hagen Kobor, "Extraterritoriale Jurisdiktion und Regelungshoheit" in Kooperative Amtsermittlung im Verwaltungsrecht, ed. Hagen Kobor (Baden Baden: Nomos Verlag, 2009): 210-217.

${ }^{20}$ For a more detailed overview of this problem, see recently published monograph by Claudia Kurkin, Extraterritorialität: Eine Kategorie des transnationalen Rechts (Tübingen: Mohr Siebeck, 2021): 188-189.

${ }^{21}$ See Austen L. Parrish, "The Interplay between Extraterritoriality, Sovereignty, and the Foundations of International Law" in The Extraterritoriality of Law. History, Theory, Politics, ed. Daniel S. Margolies, Umut Özsu, Maïa Pal and Ntina Tsouvala (Abingdon: Routledge, 2019): 238-248.

${ }^{22}$ See Eberhard Grabitz, "Administrative, Judicial and Legislative Activities on Foreign Territory" in Encyclopedia of Public International Law, Vol. 10 - States, Responsibility of the States, International Law and Municipal Law, ed. Rudolf L. Bindschedler, Thomas Buergenthal, Karl Doehring (Amsterdam: Elsevier, 1988): 4-6. 
res communis, execution of administration by authorities of other States has been considered lawful. Such was the situation with administration of the mining enterprises on Svalbard until $1906 .{ }^{23}$ Also the territorial lease represented a situation where the administration of one State had acted in the territory of another sovereign State. Such was the case of the territorial lease, which Sweden granted to the Grand Duchy of Mecklenburg-Schwerin over the city of Wismar (1803-1903). ${ }^{24}$

Cases of co-administration represent another example of such exceptions to the general rules. In Europe, such cases of co-administration had traditionally represented a tool to reconcile border disputes among the concerned States. ${ }^{25}$ One may refer to various forms of co-administration, which has existed in Europe in the past. Co-administration of the territory of Kürnbach by the authorities of the Grand Duchy of Baden and the Grand Duchy of Hesse (1815-1905) and the Belgo-German co-administration of Neutral Moresnet (1816-1919) represent salient examples of past European condominia.

However, condominia do not represent only a feature of the past. Until today, this is the case of the Pheasant Island, which has been under French-Spanish co-administration since the Treaty of Pyrenees in 1659 and which was administered for alternating periods of six months by the naval commanders of San Sebastián, Spain (1 February - 31 July) and Bayonne, France (1 August - 31 January) ${ }^{26}$ A German-Luxembourgish condominium, existing since 1815 in the aquatic border of both States, represents another example. ${ }^{27}$ The tip of one uninhabited islet, Staustufe Apach, situated near the city of Schengen, represents another example of German-Luxembourgish condominium. ${ }^{28}$

All the above-mentioned cases reflected specific arrangements among certain territories. However, international public law also acknowledged that a sovereign State may allow activities of foreign administrative authorities within its own territory. ${ }^{29}$ "Within its own territory the jurisdiction of a sovereign is exclusive, except indeed in so far as he may by his own will permit the exercise of the jurisdiction of another sovereign." ${ }^{30}$ In this respect, international public law

23 See Geir Ufstein, Svalbard Treaty, From Terra Nullius to Norwegian Sovereignty (Oslo: Scandinavian University Press, 2015): 20-22.

${ }^{24}$ See Gerhard Erasmus, "Pledge of State Territory and Property", in Encyclopedia of Public International Law, Vol. 10 - States, Responsibility of the States, International Law and Municipal Law, ed. Rudolf L. Bindschedler, Thomas Buergenthal, Karl Doehring (Amsterdam: Elsevier, 1988): 326-327.

25 See Joel H. Samuels, "Condominium Arrangements in International Practice", Michigan Journal of International Law 29, issue 4 (December 2008): 727-776.

26 See Peter Schneider, "Condominium" in Encyclopedia of Public International Law, Vol. 10 States, Responsibility of the States, International Law and Municipal Law, ed. Rudolf L. Bindschedler, Thomas Buergenthal, Karl Doehring (Amsterdam: Elsevier, 1988): 58-60.

27 ibid.

28 ibid.

29 See Harold G. Maier, "Extraterritorial Jurisdiction at a Crossroads: An Intersection Between Private and Public International Law", American Journal of International Law 76, issue 2 (April 1982): 280-320.

30 See Joseph H. Beale, "The Jurisdiction of a Sovereign State", Harvard Law Review 36, issue 3 (January 1923): 245-246. 
distinguishes between actual sovereign acts on foreign territory and requests for assistance to foreign public authorities. Both are provided by corresponding international agreements, either of a bilateral or multilateral nature.

Theoretically, activities of foreign administrative authorities may be allowed by the State unilaterally. Such unilateral administrative actions have regularly been the product of specific territorial circumstances - e.g. administration of mining works, railroads, border bridges, or highways in mountainous areas by the authorities of the neighbouring State. ${ }^{31}$ However, cases of reciprocity, as based on international agreements, seem to be more regular in international public law.

Consequently, one may argue that the phaenomenon of extraterritoriality as understood by this article - has for a long time been known in international administrative law. The fact that the scholarship of administrative law hasn't paid any larger attention to this phenomenon was not caused by non-existence of this phaenomenon in law, but rather by a strict territorial scope of administrative law. ${ }^{32}$

Ad 2). Another argument against any extraterritorial execution of competencies by the administrative authorities is a factual one. In the territory of their own State, the authority has all measures to act and to execute its own decisions. The situation is quite different in the territory of another State, where any effective execution of a decision will necessarily require co-operation with domestic authorities. $^{33}$

Reflecting these problems, the States have traditionally opted for a regime of "decentralised" control, when entering into international agreements. In this model, the authorities of the concerned States also execute control functions vis-ávis foreign subjects, being entitled to execute certain activities based on a foreign licence, or certificate. The system of driving permits, as established by the international conventions in the field of road traffic ${ }^{34}$ represents a salient example of the "decentralised" system of administrative control in practice. While the Contracting Parties to this Convention provide for mutual recognition of driving permits, the execution of control upon the holders of such licences remains in the competence of the administrative authorities of those Contracting Party, in which territory the holder of such permit drives. ${ }^{35}$

Consequently, the "decentralised" system of administrative control reflected not only the notion of territorial sovereignty of the State, but also the fact that the

${ }^{31}$ See Sara McLaughlin Mitchell, Paul R. Hensel, "International Institutions and Compliance with Agreements", American Journal of Political Science 51, issue 4 (October 2007): 721-737.

${ }^{32}$ See Hernán P. Loose, "Administrative law and international law: The encounter of an odd couple", in Making Transnational Law Work in the Global Economy: Essays in Honour of Detlev Vagts, ed. Pieter H. F. Bekker, Rudolf Dolzer, Michael Waibel (Cambridge: Cambridge University Press, 2010): 380-405.

${ }^{33}$ See Michel Audit, "Compétence extraterritorial et droit administratif", in La compétence (Paris: Travaux de l'AFDA, Colloques et débats, 2008): 69-78.

${ }^{34}$ International Convention on Road Traffic of 1909, Geneva Convention on Road Traffic of 1949, Vienna Convention on Road Traffic of 1968 etc.

35 See Kenneth Armstrong, "Mutual Recognition" in The Law of the Single European Market, Unpacking the Premises, ed. Catherine Barnard, Joanne Scott (Oxford: Hart Publishing, 2002): 225-268. 
holder of a driving permit must comply with the public law of the State of destination. Thus - in general - control over holders of foreign licences by the administrative authorities of those States which possess sovereignty over the territory has been considered as the most viable option in administrative law. ${ }^{36}$

Ad 3). Lastly, another argument against any extraterritorial execution of competences of administrative authorities reflects the legal position of the addressee of such an execution. When facing its own administration, the addressee may defend his rights pursuant to his own domestic law and approach to the domestic system of administrative jurisdiction accordingly. ${ }^{37}$

However, the situation appears to be quite different in those cases when foreign administrative authorities would act vis-á-vis citizens of another State. ${ }^{38}$ The fact is that such administrative authority will, in principle, follow its own domestic law - both substantive and procedural. ${ }^{39}$ Therefore, the addressee of the administrative action will be confronted with the application of a foreign legal regime of public law. Also, a prospective defence against any measures of foreign administration is - in principle - possible only before the courts of administrative justice of that State on behalf of which the authorities are acting. ${ }^{40}$

Consequently, the difficulties arising on the part of any addressee who faces measures of any foreign administrative authority in the territory of his own State, represents another major obstacle for the notion of extraterritoriality in administrative law.

\section{Extraterritoriality revisited in administrative law}

Despite the above-mentioned major arguments against extraterritoriality, a particular model of control has emerged which is being referred to as a "competitive" model in legal scholarship. ${ }^{41}$ Under this model, the holder of a licence is subject to the control of his domestic administrative authority. Currently, this model is frequently being used in those fields of EU law which provide for mutual recognition of licences. In the EU law on credit institutions, the Directive 2013/36/EU provides ${ }^{42}$ that "the competent authorities of the home Member State shall, without delay, take all appropriate measures to ensure that the credit institution concerned remedies its non-compliance or takes measures to avert the risk of non-compliance. The

\footnotetext{
${ }^{36}$ See Pietro Pellegrino, "Réflexions autour du principle du pays d'origine", Revue trimestrielle de droit de l'Union européenne 46, issue 6 (September 2010): 555-558.

${ }^{37}$ See Maxence Chambon, M. "L'espace et le territoire : le droit public à l'épreuve de l'extranéité", Civitas Europa 35, issue 2 (2015): 95-121.

${ }^{38}$ See Günther Handl, "Extraterritoriality and Transnational Legal Authority", in Beyond Territoriality. Transnational Legal Authority in an Age of Globalisation, ed. Günther Handl, Joachim Zekoll, Peer Zumbansen (Leiden: Martinus Nijhoff Publishers, 2012): 3-9.

${ }^{39}$ See Jakub Handrlica, “A Treatise for International Administrative Law”, The Lawyer Quarterly 10, issue 4 (December 2020): 462-475.

${ }^{40}$ See Emilie Chevalier, Olivier Dubos, "The Notion of "Transnationality" in Administrative Law, Taxonomy and Judicial Review", German Law Journal 22, issue 3 (May 2021): 325-343.

${ }^{41}$ See Armstrong, "Mutual Recognition", 226-228.

${ }^{42}$ Art. 41.
} 
competent authorities of the home Member State shall communicate those measures to the competent authorities of the host Member State without delay."

The EU law on collective investment in transferable securities also follows a similar approach. Here, Directive 2009/65/ES provides ${ }^{43}$ that "the competent authorities of the management company's home Member State shall, at the earliest opportunity, take all appropriate measures to ensure that the management company concerned provides the information requested by the management company's host Member State pursuant to paragraph 2 or puts an end to the breach. The nature of those measures shall be communicated to the competent authorities of the management company's host Member State."

The "competitive" model, upon which these mechanisms are built, reflects the fact that the administration of the home State is in the best position to evaluate compliance with the issued licence. Consequently, the "competitive" model clearly penetrates the traditional reservations against extraterritoriality in administrative law. ${ }^{44}$

The fact is, however, that execution of competences of foreign administrative authorities in the territory of other sovereign States cannot be considered a new phaenomenon. ${ }^{45}$ This feature has far deeper roots in the tradition of various jurisdictions in Europe. While the mainstream scholarship of administrative law haven't paid much attention to this feature, the phaenomenon of extraterritoriality attracted considerable attention of those authors in the first decades of the $20^{\text {th }}$ century, dealing with international administrative law. ${ }^{46}$ The following examples triggered the particular attention of this scholarship:

In 1829 the Austrian Empire and the Kingdom of Bavaria concluded an international agreement dealing with the execution of safety administration in the mining works of Dürrenberg, situated partly on Austrian territory and putting these under the competence of Bavarian mining authorities (, unter der landherrlichen Oberaufsicht Bayerns "). ${ }^{47}$ In a similar vein, an international agreement concluded between the Grand Duchy of Baden and the Swiss Confederation in 1854, provided for a regime of administration of the border bridge in Thurgau. In this case, the Contracting Parties agreed that the police of either of these Parties would also

${ }^{43}$ Art. 21.

${ }^{44}$ See Niamh Moloney, EU Securities Regulation (Oxford: Oxford University Press, 2012): 145-147. Also see Handrlica, J. "Is there an EU international administrative law? A juristic delusion revisited", European Journal of Legal Studies 12, issue 2 (October 2020): 79-116.

${ }^{45}$ See James Gordley, "Extra-territorial Legal Problems in a World Without Nations: What a Medieval Jurist Could Teach Us", in in Beyond Territoriality. Transnational Legal Authority in an Age of Globalisation, ed. Günther Handl, Joachim Zekoll, Peer Zumbansen (Leiden: Martinus Nijhoff Publishers, 2012): 35-52.

46 See Prospero Fedozzi, Il diritto amministrativo internazionale, Nozione sistematiche (Perugia: Unione tipografica cooperativa, 1901): 56-58, Karl Neumeyer, Internationales Verwaltungsrecht, Allgemeiner Teil. (Zürich/Leipzig: Verlag für Recht und Gesellschaft AG, 1936): 476-481, Umberto Fragola, Diritto amministrativo internazionale, Manuali di szienze giuridiche ed economiche (Napoli: Pallerano \& Del Gaudio, 1951): 450-458 etc.

47 See Karl Neumeyer, Internationales Verwaltungsrecht, Innere Verwaltung III. (München: J. Schweitzer Verlag, 1926): 17-18. 
execute their duties in the sovereign territory of the other Party, based on reciprocity. ${ }^{48}$

The post-WWI period also witnessed a number of similar agreements, providing for extraterritorial competences of administrative authorities in territories of foreign States. In an agreement concluded between France and Germany in 1920, the regime of administration on the border bridges situated on the Rhine River was agreed. ${ }^{49}$ Also here, based on reciprocity, the Contracting Parties allowed for execution of competences by the police authorities of another Party with respect to their own border territory.

An agreement between France and Germany, concluded in 1935 to settle the issue of mining works situated in the territory of the Saarland represents another example of extraterritoriality in administrative law. ${ }^{50}$ Pursuant to this agreement, French mining authorities were competent to execute their powers over all mining works situated in the territory and to apply French public law when acting in the territory of Germany. ${ }^{51}$ At the same time, the agreement provided that any cases of damages were to be regulated by German civil law.

Similar agreements, providing for extraterritorial competences of administrative authorities, were also adopted in the post-WWI region of Central Europe and in the Balkan region.

Thus, the agreement adopted by the Czechoslovak Republic and Poland in 1927, provided for rules on railroad administration in the border areas between both Contracting Parties. The agreement provided that the Polish railway administration was competent to execute competencies over the railroads also in the territory of Czechoslovakia, in particular on the border areas of Tarnów-Leluchow, PiwnicznaZegiestów and Nowy Lupków-Cisna. When executing their competencies in the territory of Czechoslovakia, the Polish railroad authorities were to apply Polish public law. ${ }^{52}$

The agreement, adopted by the Republic of Austria and the Czechoslovak Republic, adopted in 1921, provided for a special regime on construction of a water pipeline to supply the border city of Breclav (Lundeburg). Pursuant to this agreement, the Austrian administrative authorities were competent to approve the construction of the entire water pipeline, regardless of whether it was to be constructed in the territory of Austria or Czechoslovakia. ${ }^{53}$

Lastly, the agreement between the Republic of Greece and the Kingdom of Yugoslavia, adopted in 1926, provided for a special regime of administration of the Ghevgheli-Salonica railway and of the Yugoslav free zone in Salonica. This agreement also provided for competencies of the Yugoslav customs administration

${ }^{48}$ See Heinrich Rettich, Völker- und Staatsrechtliche Verhältnisse des Bodensees. Historisch und juristisch untersucht (Tübingen: Verlag der H. Lauschen Buchhandlung, 1884): 44-45.

49 See Alfred Lederle, Das Recht der internationalen Gewässer unter besonderer Berücksichtigung Europas: eine völkerrechtliche Studie (Berlin: J. Bensheimer, 1920): 25-26.

${ }^{50}$ See Sidney B. Fay, "Saar Mines Agreement", Current History 41, issue 4 (1935): 490-491.

${ }^{51}$ Art. 32.

52 Art. 4.

${ }^{53}$ Art. V. 
in the free zone in Salonica, i.e. in the sovereign territory of Greece. ${ }^{54}$ Pursuant to this agreement, the customs officials of the Kingdom of Yugoslavia, were empowered to execute their functions in the free zone situated in the port of Salonica and apply their own domestic (Yugoslav) public law. ${ }^{55}$

Thus, this short excursion has clearly demonstrated that the notion of extraterritoriality has for decades represented an integral part of administration in various jurisdictions across Europe. Various States entered into agreements dealing with specific administrative matters where certain transboundary element appeared. Consequently, one can hardly argue that the phaenomenon of extraterritoriality represents a new feature in administrative law.

Analysing various international agreements concluded in the past between various European States, the conclusion is rather different. Indeed, extraterritoriality represented an integral - albeit not regularly thematised - part of the administrative law of various States of Europe. To paraphrase Molière's Le Bourgeois gentilhomme, 'administrative law has always been analysing extraterritoriality, even without being aware of it'. ${ }^{56}$

Analysing the above-mentioned international agreements, this article also aims to argue that the feature of extraterritoriality represents an integral part of ius publicum europaeum commune. This solution to transboundary problems in administration appears spontaneously in different administrative traditions. ${ }^{57}$ Consequently, extraterritoriality does not represent a feature which is strictly connected to one particular legal region, but is shared across Europe. Its introduction must be considered as a rational choice of policy makers, which have been aware of arguments against this feature, but have accepted certain negative consequences as a quid pro quo for the obvious benefits arising.

\section{Conclusions}

The mainstream scholarship of administrative law has not paid much attention to the feature of extraterritoriality. However, this approach has not been caused by non-existence of this feature, but rather by longue durée of territorial paradigm of the scholarship. ${ }^{58}$ The fact is that extraterritoriality has always represented an integral - albeit not regularly analysed - part of administrative law.

54 See Dragan Bakič, "The Port of Salonica in Yugoslav Foreign Policy 1919-1941", Balcanica 43 (January 2012): 191-219.

${ }^{55}$ See Shai Srougo, "The Fall of the Balkan Port: Geopolitical Dynamics and the the Decline of the Free Zone in Thessaloniki, 1923-1939”, Journal of Historical Geography 72 (April 2021): 63-71.

${ }^{56}$ Also see Péter D. Szigeti, "In the Middle of Nowhere: The Futile Quest to Distinguish Territoriality from Extraterritoriality" in The Extraterritoriality of Law. History, Theory, Politics, ed. Daniel S. Margolies, Umut Özsu, Maïa Pal and Ntina Tsouvala (Abingdon: Routledge, 2019): 30-39 (here, the author analyses difficulties in delimiting "territoriality" from "extraterritoriality").

${ }^{57}$ See Giacinto Della Cananea, "Ius Publicum Europaeum: Divergent National Traditions or Common Legal Patrimony?", in Administrative Law in Europe: Between Common Principles and National Traditions, ed. Matthias Ruffert (Groningen: Europa Law Publishing, 2015): 123-124.

${ }^{58}$ See Abudo Gonzalez, "The overcoming of territorial paradigm and its effects in administrative law", 157. 
Also, extraterritoriality as an instrument to reconcile special transboundary circumstances seems to appear in various jurisdictions, even without any harmonisation, or unification by the means of law. Thus, one may argue that extraterritoriality as a tool represents - despite major dogmatic reservations against this feature - a part of ius publicum europaeum commune.

\section{Bibliography}

1. Abudo Gonzalez, J. "The overcoming of territorial paradigm and its effects in administrative law", Revista de derecho politico 103 (December 2018): 157-190.

2. Amvrazi, A., Farr Louis, D., Shugart, D. 111 Places in Athens That You Shouldn't Miss. Leck: Emons Verlag GmbH, 2018.

3. Armstrong, K. "Mutual Recognition" in The Law of the Single European Market, Unpacking the Premises, edited by Catherine Barnard, Joanne Scott, 225-268. Oxford: Hart Publishing, 2002.

4. Audit, M. "Compétence extraterritorial et droit administratif", in La competence, 69-78. Paris: Travaux de l'AFDA, Colloques et débats, 2008.

5. Bakič, D. "The Port of Salonica in Yugoslav Foreign Policy 1919-1941”, Balcanica 43 (January 2012): 191-219.

6. Baldus, M. Transnationales Polizeirecht. Baden Baden: NomosVerlag, 2001.

7. Battini, S. "Globalisation and Extraterritorial Regulation: An Unexceptional Exception" in Values in Global Administrative Law, edited by Gordon Anthony, Jean-Bernard Auby, John Morison and Tom Zwart, 65-80. London: Hart Publishing, 2011.

8. Beale, J., H. "The Jurisdiction of a Sovereign State", Harvard Law Review 36, issue 3 (January 1923): 245-246.

9. Biaggini, G. "Die Entwicklung eines internationalen Verwaltungsrechts als Aufgabe der Rechtswischenschaft" in Die Leistungsfähigkeit der Wissenschaft des Öffentlichen Rechts, edited by George Nolte, Ralph Poscher, Christian Hillgruber, Uwe Volkmann, 413-440. Berlin: De Gruyter Recht, 2008.

10. Cassese, S., Napolitano, G., Casini, L. "Towards multipolar administrative law: a theoretical perspective", International Journal of Constitutional Law 12, issue 2 (April 2014): 354-356.

11. David, A. Inspektionen im Europäischen Verwaltungsrecht. Berlin: Duncker \& Humblot, 2003.

12. D'Avigno, D. "Extraterritoriality of swaps regulation and regulatory arbitrage", Journal of Regulatory Economics 56, issue 2-3 (December 2019): 167-187.

13. Della Cananea, G. "Beyond the State: the Europeisation and globalisation of procedural administrative law", European Public Law 9, issue 4 (December 2004): 563-578.

14. Della Cananea, G. "Transnational public law in Europe: Beyond the lex alius loci", in Transnational law, edited by Miquel Maduro, Kaarlo Tuori and Suvi Sankari, 321-345. Cambridge: Cambridge University Press, 2014.

15. Della Cananea, "Ius Publicum Europaeum: Divergent National Traditions or Common Legal Patrimony?", in Administrative Law in Europe: Between Common Principles and National Traditions, edited by Matthias Ruffert, 123-158. Groningen: Europa Law Publishing, 2015.

16. Della Cananea, G., "Administrative Law Beyond the State" in The Oxford Handbook of Comparative Administrative Law, edited by Peter Cane, Herwig C. H. Hofmann, Eric C. Ip and Peter L. Lindseth, 675-686. Oxford: Oxford University Press, 2020. 
17. Erasmus, G. "Pledge of State Territory and Property", in Encyclopedia of Public International Law, Vol. 10 - States, Responsibility of the States, International Law and Municipal Law, edited by Rudolf L. Bindschedler, Thomas Buergenthal, Karl Doehring, 326-327. Amsterdam: Elsevier, 1988.

18. Fay, S., B. "Saar Mines Agreement", Current History 41, issue 4 (1935): 490-491.

19. Fedozzi, Il diritto amministrativo internazionale, Nozione sistematiche. Perugia: Unione tipografica cooperativa, 1901.

20. Fragola, U. Diritto amministrativo internazionale, Manuali di szienze giuridiche ed economiche. Napoli: Pallerano \& Del Gaudio, 1951.

21. Grabitz, E. "Administrative, Judicial and Legislative Activities on Foreign Territory" in Encyclopedia of Public International Law, Vol. 10 - States, Responsibility of the States, International Law and Municipal Law, edited by Rudolf L. Bindschedler, Thomas Buergenthal, Karl Doehring, 4-6. Amsterdam: Elsevier, 1988.

22. Handl, G. "Extraterritoriality and Transnational Legal Authority", in Beyond Territoriality. Transnational Legal Authority in an Age of Globalisation, edited by Günther Handl, Joachim Zekoll, Peer Zumbansen, 3-9. Leiden: Martinus Nijhoff Publishers, 2012.

23. Handrlica, J. "Revisiting International Administratve Law as a Legal Discipline", Zbornik Pravnog Fakulteta Sveučilišta u Rijeci 39, issue 3 (December 2018): 12371258.

24. Handrlica, J. “A Treatise for International Administrative Law”, The Lawyer Quarterly 10, issue 4 (December 2020): 462-475.

25. Handrlica, J. "Is there an EU international administrative law? A juristic delusion revisited", European Journal of Legal Studies 12, issue 2 (October 2020): 79-116.

26. Haskell, J., D. "Ways of doing extraterritoriality in scholarship" in The Extraterritoriality of Law. History, Theory, Politics, edited by Daniel S. Margolies, Umut Özsu, Maïa Pal and Ntina Tsouvala, 20-25. Abingdon: Routledge, 2019.

27. Heller, H. Sovereignty. A Contribution to the Theory of Public and International Law, edited by David Dyzenhaus. Oxford: Oxford University Press, 2019.

28. Chambon, M. "L'espace et le territoire : le droit public à l'épreuve de l'extranéité", Civitas Europa 35, issue 2 (2015): 95-121.

29. Chevalier, E., Dubos, O. "The Notion of "Transnationality" in Administrative Law, Taxonomy and Judicial Review”, German Law Journal 22, issue 3 (May 2021): 325343.

30. Kment, M. Grenzüberschreitendes Verwaltungshandeln. Transnationale Elemente deutscher Verwaltungsrecht. Tübingen: Mohr Siebeck, 2010.

31. Kobor, H. "Extraterritoriale Jurisdiktion und Regelungshoheit" in Kooperative Amtsermittlung im Verwaltungsrecht, edited by Hagen Kobor, 210-217. Baden Baden: Nomos Verlag, 2009.

32. Kuo, M., S. "From administrative law to administrative legitimation: Transnational administrative law and the process of European integration", International \& Comparative Law Quarterly 61, issue 4 (October 2012): 855-879.

33. Kurkin, C. Extraterritorialität: Eine Kategorie des transnationalen Rechts. Tübingen: Mohr Siebeck, 2021.

34. Lederle, A. Das Recht der internationalen Gewässer unter besonderer Berücksichtigung Europas: eine völkerrechtliche Studie. Berlin: J. Bensheimer, 1920.

35. Lehman, M. "Legal Fragmentation, Extraterritoriality and Uncertainty in Global Financial Regulation", Oxford Journal of Legal Studies 37, issue 2 (2017): 406-437.

36. Lind, A., Reichel, J. (eds), Administrative Law Beyond the State, Nordic Perspectives. Leiden: Brill Nijhoff Publishers, 2015. 
37. Loose, H., P. "Administrative law and international law: The encounted of an odd couple", in Making Transnational Law Work in the Global Economy: Essays in Honour of Detlev Vagts, edited by Pieter H. F. Bekker, Rudolf Dolzer, Michael Waibel, 380405. Cambridge: Cambridge University Press, 2010.

38. Maier, H., G. "Extraterritorial Jurisdiction at a Crossroads: An Intersection Between Private and Public International Law", American Journal of International Law 76, issue 2 (April 1982): 280-320.

39. McLaughlin Mitchell, S., Hensel, P., R. "International Institutions and Compliance with Agreements", American Journal of Political Science 51, issue 4 (October 2007): 721737.

40. Mendes, J. "Administrative Law Beyond the State", in Global Administrative Law and European Administrative Law. Relationship, Legal Issues and Comparison, ed. Edoardo Chiti, Bernardo G. Mattarella, 111-132. Berlin: Springer Verlag, 2011.

41. Moloney, N. EU Securities Regulation. Oxford: Oxford University Press, 2012.

42. Napolitano, G. "Administration Beyond the State", in Comparative Administrative Law, edited by Susan Rose-Ackermann, Peter L. Lindseth, 320-322. London: Edward Elgar, 2010.

43. Neumeyer, K. Internationales Verwaltungsrecht, Innere Verwaltung III. München: J. Schweitzer Verlag, 1926.

44. Neumeyer, K. Internationales Verwaltungsrecht, Allgemeiner Teil. Zürich/Leipzig: Verlag für Recht und Gesellschaft AG, 1936.

45. Parrish, A., L. "The Interplay between Extraterritoriality, Sovereignty, and the Foundations of International Law" in The Extraterritoriality of Law. History, Theory, Politics, edited by Daniel S. Margolies, Umut Özsu, Maïa Pal and Ntina Tsouvala, 238248. Abingdon: Routledge, 2019.

46. Pellegrino, P. "Réflexions autour du principle du pays d'origine", Revue trimestrielle de droit de l'Union européenne 46, issue 6 (September 2010): 555-558.

47. Rettich, H. Völker - und Staatsrechtliche Verhältnisse des Bodensees. Historisch und juristisch untersucht. Tübingen: Verlag der H. Lauschen Buchhandlung, 1884.

48. Ruffert, M. "Common Principles and National Traditions: Which Perspective for European Administrative Legal Scholarship", Administrative Law in Europe: Between Common Principles and National Traditions, edited by Matthias Ruffert, 215-220. Groningen: Europa Law Publishing, 2015.

49. Săraru, C.-S. European Administrative Space - recent challenges and evolution prospects, ADJURIS - International Academic Publisher, Bucharest, 2017.

50. Schmidt-Assmann, E. "Administrative Law in Europe: Between Common Principles and National Traditions", in Administrative Law in Europe: Between Common Principles and National Traditions, edited by Matthias Ruffert, 3-36. Groningen: Europa Law Publishing, 2015.

51. Schneider, P. "Condominium" in Encyclopedia of Public International Law, Vol. 10 States, Responsibility of the States, International Law and Municipal Law, edited by Rudolf L. Bindschedler, Thomas Buergenthal, Karl Doehring, 58-60. Amsterdam: Elsevier, 1988.

52. Srougo, S. "The Fall of the Balkan Port: Geopolitical Dynamics and the the Decline of the Free Zone in Thessaloniki, 1923-1939”, Journal of Historical Geography 72 (April 2021): 63-71.

53. Szigeti, P., D. "In the Middle of Nowhere: The Futile Quest to Distinguish Territoriality from Extraterritoriality" in The Extraterritoriality of Law. History, Theory, Politics, edited by Daniel S. Margolies, Umut Özsu, Maïa Pal and Ntina Tsouvala, 30-39. Abingdon: Routledge, 2019. 
54. Tönningsen, G. Grenzüberschreitender Bankenaufsicht in der Europäischen Union. Tübingen: Mohr Siebeck, 2018.

55. Ufstein, G. Svalbard Treaty, From Terra Nullius to Norwegian Sovereignty. Oslo: Scandinavian University Press, 2015.

56. Verdier, P., H. "New Financial Extraterritriality", George Washington Law Review 87, issue 2 (March 2019): 239-314.

57. Yldiz, E. "Extraterritoriality Reconsidered" in The Extraterritoriality of Law. History, Theory, Politics, edited by Daniel S. Margolies, Umut Özsu, Maïa Pal and Ntina Tsouvala, 215-227. Abingdon: Routledge, 2019. 